\title{
Virtual Sales Versus Classical Sales: A Perspective From Brazilian Airlines Customers
}

\author{
Eduardo Silva da Silva ${ }^{1} \&$ Guilherme Bridi ${ }^{2}$ \\ ${ }^{1}$ Tourism, The Methodist University Center, IPA, Porto Alegre, Brazil \\ ${ }^{2}$ Regional Development, The University of Santa Cruz do Sul, Brazil \\ Correspondence: Guilherme Bridi, PH.D. Regional Development, The University of Santa Cruz do Sul, Brazil.
}

Received: December 19, 2018

Accepted: January 8, 2019

Online Published: January 22, 2019

doi:10.5430/ijba.v10n1p87

URL: https://doi.org/10.5430/ijba.v10n1p87

\begin{abstract}
The present paper aims to contribute to the debate about the use of digital marketing and relationship marketing tools for travel sales, and their respective reflexes in the customers preferences by virtual or classical sales channels of airlines tickets in Brazil. Therefore, it was applied a survey with 80 regular customers from domestic flights. It was identified that most of the respondents tend to buy their tickets into virtual sales channels, mainly in those that are better organized and offer the best rates. For those who chose for traditional channels tend to buy tickets from the airlines that focus on keeping a good service throughout the sales process, and also analyzing factors such as quality of service and safety. It was also concluded that it is extremely important to invest in digital marketing and relationships tools, once passengers are each more looking for a fair price combined with good quality.
\end{abstract}

Keywords: tourism, digital marketing tools, airlines, customers

\section{Initial Considerations}

This research has focused on purchase forms of airline tickets in Brazil, both into traditional and virtual channels. Likewise, it was also analyzed the effectiveness of the use of digital and relationship marketing tools in the main sales channels of Brazilian carriers. The survey took place between August and October 2017, with a sample of 80 passengers from Porto Alegre International Airport-Salgado Filho, which are also customers of the four major Brazilian carriers: Avianca, Azul, Gol and Latam.

If the travel market currently includes different actors and virtual sales channels (airline's web portals and travel conglomerates) and traditional (travel agency or airline desk), this study aims to answer the following questions: What are the sales channels most used by airline's customers? What reasons led them to choose their preferred sale's channel?

This work aimed to contribute to the debate about the use of digital marketing tools for the travelling business such as their respective effects on the preferences of users on traditional and / or virtual airline's sales channels in Brazil.

Tourism as economic booster is gaining more space in several markets around the world. According to the Exame Magazine (2017), tourism activities increased about $4 \%$ in 2016 in relation to number of travelers, totalizing 1,2 billion people travelling on planet earth. According to this very same publication, the European continent remains as the first choice of the tourists, despite all the incidents involving terrorism in recent years. Countries as France and Spain already understood the importance of the tourist activities for their economy, becoming excellent cases of success regarding the development of politics towards tourism's field.

Currently, the market of civil aviation in Brazil is ruled by four main airlines: Avianca, Azul, Gol and Latam, which withholds about $90 \%$ of domestic flights market share. These carriers also are responsible to operate on most of brazilian airports and provide international flights. Regarding to the field of research, according to INFRAERO (2015), Salgado Filho Airport has an average flow of 23.000 people/ day, with an estimative of almost five thousand people working there. It also provides more than 240 daily flights, domestic and international.

In complement to this, for Marin (2007), using information technologies (IT's), such as marketing tools and virtual sales of tourism services consist as main vectors that contribute for the growth of the sector. Historically, the internet as a new tool of selling products and services, combined with the deregulation of air transport caused severe 
changing on the tourism market, specially regarding the selling process or airlines tickets (BRIDI and SANTOS, 2012). In Brazilian scenario, air tickets virtual sales channels become more popular after GOL came into the market, on early 2000's. One of its main policies was to sell tickets strictly using internet, being them followed by other carriers such as LATAM, who didn't want to lose its market share. After this, on 2004, virtual sales of tourist products and services increase about $47 \%$, totalizing $20 \%$ of tourism services and sales (OTAVIANI LONGHINI, POGGI and BORGES, 2005). On the following years, tourism virtual sales became more and more popular in Brazil, reaching millions of new customers every year.

Therefore, despite of that, it is possible to consider that virtual sales took place in Brazil recently, especially on the last 10 years. This is a valuable information, once it points out that many customers, especially older ones, could still prefer to buy their tickets using classic sales channel, for safety or convenience purposes. All these numbers and prior data bring up the importance of the discussion about which are the favorite sales channels by customers, and for what reasons did they choose one or another channel. Thus, it is valuable to believe that researches that seek to discuss these fields of study, regarding the ways of selling airlines tickets in Brazil are important and justifiable.

\section{Theoretical Referencial}

\subsection{The Tourism in the Age of the Digital Marketing}

Globally, marketing as tool for tourism is developing innumerable possibilities due to the promotion of tourist destinations. As well as the marketing field, tourism sector was also developed and became a social phenomenon that currently reaches millions of people and move billions of dollars. According to World-wide Organization of the Tourism (OMT, 2016), the tourist activities are successfully developing itself in past few decades, stimulating the social and economic growth of many regions in the world.

Regarding customers or tourists, it is observed that they are adapted to the recent technological revolution, becoming, each time, more far from the label of the vulnerable and total unprovided of knowledge tourist. In accordance with Morrison (2012), the online marketing is basically changing the way as the tourists get their information about tourism and hospitality services and how they book their trips. With the Internet, tourists suddenly reached out the possibility to previously know innumerable information about their place of desire or find out which and where is the best hotel to stay, best tours, best car rental company, using sites and apps that are specialized on trip services, with nothing but a cellphone connected on internet.

In relation to this so called digital age, Longo (2014) affirms that we've already crossed that line, and in fact, we are currently living post-digital age, since the technology is no longer a privilege, becoming them a basic necessity for the contemporary society. The author stands out that in this after-digital world, the technology is something so natural that we don't even notice it, since it is very usual and present in our lives.

From this analysis, it is possible to realize that there's no more excuses for an ordinary company to underestimate the power of this free information age and how does it affect customers choices. These global customers have, each time more, a leading trace on their way of doing business and planning their trips. On the same direction, Longo (2014) consider that

Developing the digital technology and to leaving the analogical world behind was a wonderful moment lived by who were born in $20^{\text {th }}$ century, but it is already an overcame chapter. There's no more borders between the digital world does and real world, between online and off-line, from now on, everything is a single thing. The digital technology was absorbed and is now part of all the aspects of the life, all the time. Therefore, it is time to care about the impacts that this ubiquity provokes in the present and in the future. We are leaving, therefore, the digital age and quickly entering in the after-digital age. (LONGO, 2014: s.p.)

In this context, it is extremely important to analyze and to debate the necessity of developing ways of approaching tourists to these new sources of sales and media channels. It is also considered that the digital marketing has as its main goal to approach customers and companies and, regarding tourism, to stimulate the leisure desires. In such a way, carriers, historically responsible for the huge tourism development, in the decade of 1950, also adapt this new technological reality. Therefore, it becomes necessary to debate relations between tourism and air transport carriers.

\subsection{Brazilian Civil Aviation}

Concerning Brazilian current civil aviation market, there are four major carriers that dispute the preference of travelers, as previously mentioned. According to data shared by the Ministry of Transportation, Ports and Civil Aviation, through the SAC report (2017), on domestic flights, there was an average increase of $3.5 \%$ in the number 
of seats offered Available Seat Kilometers or available seat kilometers (ASK) and in relation to demand Revenue Passenger Kilometers or Passenger Kilometer Transported (RPK), there was also an increase of $5.40 \%$ in comparison between March 2016 and 2017, as well as a positive balance on the occupancy rate, which increased 1.87\% over the same period comparison.

Airlines, Gol, Avianca and Azul had, respectively, an increase of 7.41\%, 7.96\% and 5.20\% related to passenger's transportation, comparing data from March 2016 and March 2017. Differing from these positive results, Latam showed a decrease of $10 \%$ in market share during the same period.

According to the data exposed above, it is considered that the civil aviation sector in Brazil has been growing in recent years. Regarding tourism, campaigns sponsored by the Ministry of Tourism, allied to the growth of regional flights as well as the use of IT's for carriers could be considered explanations for these positive results. Thus, in line with the main purpose of this research, it is required to discuss about the use of digital marketing tools by Brazilian airlines.

\subsubsection{Digital Marketing and Virtual Sales Channels of Brazilian Airlines}

As it was presented previously, the services market share had a major shifting when internet took place globally. In the field of tourism and air transportation, carriers that previously had their sales by traditional channels as tool frees lines or airport stores suddenly changed their strategy, starting to invest on virtual channels, such as chats and social networks, medias among others. According to Guimarães Junior (2012), the creation of the Consumer Protection Code (CDC) in the 1990s, also originate the "SAC"-Customer Service that guarantees the companies necessarily have to maintain a phone service to its customers. However, this kind of service is no longer enough, once customers are using each more technologic resources to purchase products in general.

Regarding brazilian airlines, the beginning of the low fare and low cost age, which occurred in the early 2000s, provided news concepts on travel sales channels. In this new reality, virtual sales portals have come to occupy a leading role on airlines tickets, sales. As an example, it can be cited the pioneering web portal www.voegol.com.br (GOL), followed by web portal www.e-tam.com.br(Current LATAM). (PALHARES 2001)

Thus, other Brazilian airlines had to adapt to these new market rules. According to the newspaper's site The State of São Paulo (2016) Data from the National Survey by Household Sampling (PNAD) conducted by the Brazilian Institute of Geography and Statistics (IBGE) in 2015, more than 100 millions of brazilians have currently internet access, $89 \%$ by smartphones. This sort of information reveals how important is for carriers to invest on digital marketing and online sales channels, specially developing sales apps that allow customers purchase their tickets quickly and with more reliability.

According to these information, currently, the airlines used on this study keep a web portal as main sale channel, as well as profiles in the main social nets (Facebook and Twitter). All carriers, in the same way, value the interactiveness, combined with online mailing, beyond keeping its additional sales channels and partners (travel agencies, operators, among others).

In this direction, actions of relationship and virtual marketing are prominent (PETROCCHI, 2005), with the main goal to customer's fidelity. This author still considers as key factor for an effective relationship marketing:

a) Financial advantages to the customers;

b) Exclusive treatment;

c) Good communication with customers, using technological resources.

Mileage member cards and other fidelity programs are also good examples of relationship marketing strategies currently adopted by airlines.

\section{Methodology}

\subsection{Nature of the Research}

The present research consists in a case study. For Yin (2010) the case study is an inquiry of phenomena that are currently occurring and that, for its complexity, does not have control on. In complement of Yin's concept (2010), Ludke and Andres (2012) consider as main characteristics of a case study:

a) The seek for the discovery of new elements;

b) The object is analyzed inside of its context;

c) Aims to express the reality; 
d) It is based on multiple sources of information;

e) Generally, it uses an accessible language;

Combined with the case study, the procedure of mixing research was also used, once it encloses the qualitative and quantitative methods of research. For Creswell (2010), the use of the mixing method provides better understanding of the subject in the research, since distinct types of data are analyzed. For Yin (2010) the case studies do not restrict to the qualitative research, using as well, quantitative evidences.

The data was collected using the following instruments: an interview form, an online questionnaire and constant searches in Brazilian airlines web portals, during September and October of 2017.

The first stage counted on actual interviews, using a form that contains open and closed questions, as well as questions in scale. Based on the theories of Creswell (2010, p.255), it is given credit that the instrument contemplates "indirect information, filtered from the respondent's points of view". The researcher approached 40 passengers from domestic flights in the Salgado Filho International Airport, subdivided in 10 from each airline.

The second stage contemplated an online questionnaire with the same questions of the interview form, using Google Forms with 40 passengers of domestic flights, being 10 from each airline. All the questions of both stages were organized on 45 questions of multiple choices, 15 related to airline's choice and 30 related to purchase preferences.

\section{Results and Data Analysis}

\subsection{Sample'S Profile}

Referring stages 1 and 2, the interviews had reached a total of 80 airlines passengers from domestic flights, being 40 interviews and 40 virtual interviews. About $59 \%$ of the respondents were male (Figure 1). This data is in line with SAC's research (2014) which showed that approximately 57\% of the passengers in the Brazilian airports are male gender.

Table 1. Gender number of times this answer appeared in the survey

\begin{tabular}{ll}
\hline GENDER & INCIDENCE \\
\hline Female & 33 \\
Male & 47 \\
Others & 0 \\
\hline
\end{tabular}

Source: Author's, 2017

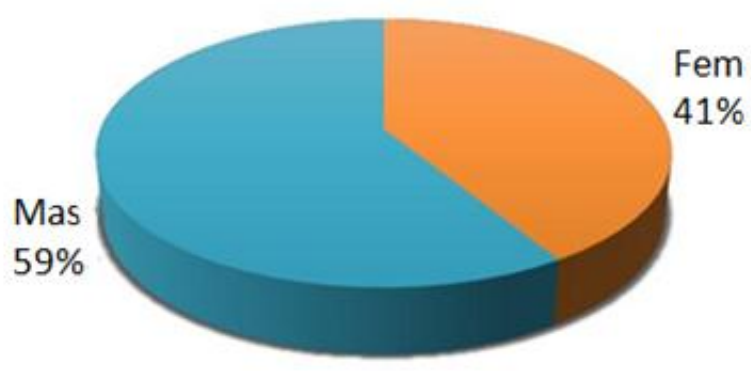

Figure 1. Gender

Source: Author's edition, 2017.

Regarding the average age, it is observed that the range between 20 and 35 years is predominant $(67 \%)$ and then, between 36 and 50 appears at $15 \%$, showing that the public who attends the airport is composed mostly by people until 50 years old, and also meets with the research conducted by the SAC in 2014. 
Table 2. Incidence about age

\begin{tabular}{ll}
\hline AGE & INCIDENCE \\
\hline (F1) 12 to 20 years & 5 \\
(F2) 21 to 35 & 54 \\
(F3) 36 to 50 year & 12 \\
(F4) 51 to 65 & 7 \\
(F5) 66 years or more & 2 \\
\hline
\end{tabular}

Source: Author's edition, 2017.

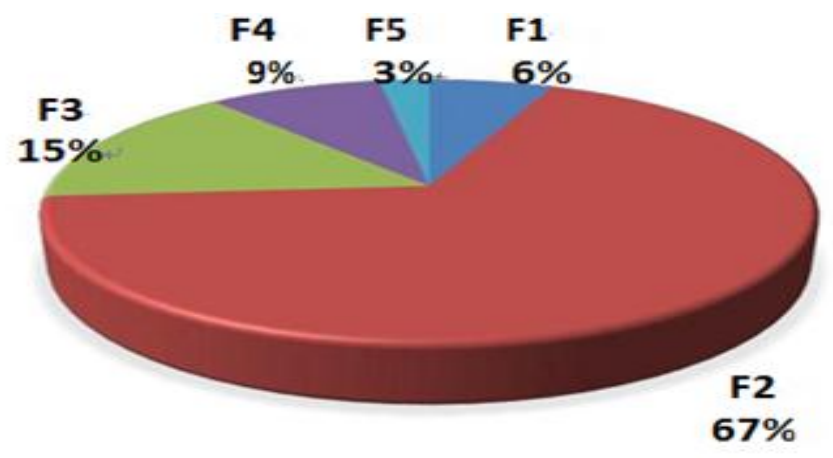

Figure 2. Age range

Source: Author's edition, 2017.

Despite the programs provided by the Federal Government of Brazil, which distribute scholarships in undergraduate programs in the country, according to information shared by Folha de São Paulo (2016), the Organization for Cooperation and Development (OECD) affirmed that only 14\% of Brazilian adults bear a college degree. That reality opposes to the results obtained on this research, once 55 of the respondents (69\%), confirmed to have higher education in their curriculum, as shown on Figure 3.

Table 3. Education level

\begin{tabular}{ll}
\hline SCHOOLING & INCIDENCE \\
\hline (EF) Elementary school & 0 \\
(MS) Highschool & 19 \\
(ES) Undergraduate & 55 \\
(PG) Graduate & 6 \\
(DR) PhD & 0 \\
\hline
\end{tabular}

Source: Author's edition, 2017

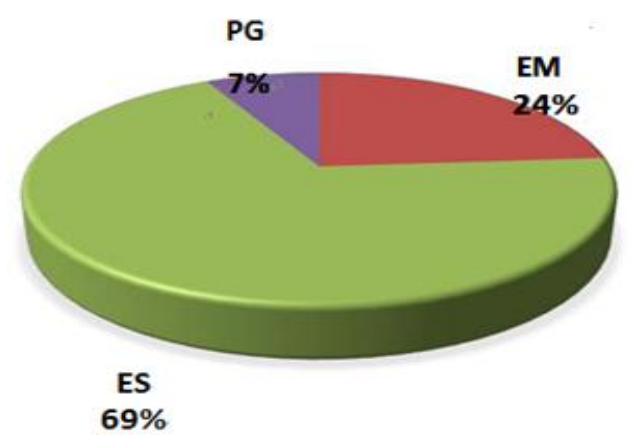

Figure 3. Education level

Source: Author's edition, 2017. 
About table and Figure 4, it is possible to notice that Salgado Filho international Airport, supply, mostly (79\%), local state residents, called "gaúchos". Other states, as Santa Catarina and São Paulo represents 5\% each, followed by Rio de Janeiro, with $4 \%$ of respondents.

Table 4. State of procedence

\begin{tabular}{ll}
\hline STATE OF PROCEDENCE & INCIDENCE \\
\hline Rio Grande do Sul & 63 \\
Santa Catarina & 4 \\
São Paulo & 4 \\
Rio de Janeiro & 3 \\
Distrito Federal & 1 \\
Minas Gerais & 1 \\
Paraná & 1 \\
Pernambuco & 1 \\
Goiás & 1 \\
Pará & 1 \\
\hline
\end{tabular}

Source: Author's edition, 2017.

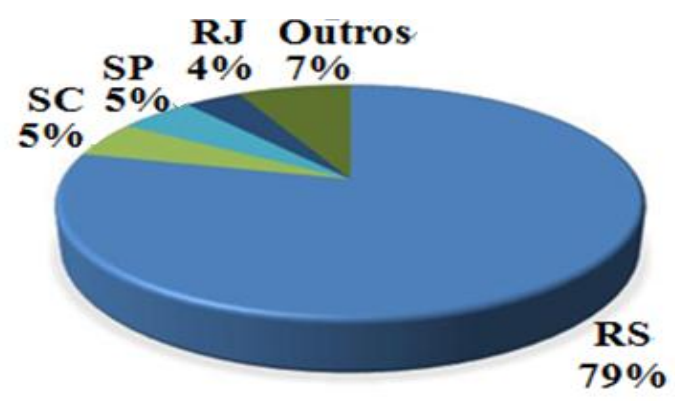

Figure 4. State of procedence

Source: Author's edition, 2017.

Despite of the fact that business tourism has a major position in Brazil and the city of Porto Alegre are in the top 5 cities that host events in the country, $68 \%$ of respondents said that their travel had, mostly, pleasure purposes (Figure $5)$ and these trips occurred at least once a year (32\%, Figure 6).

Table 5. Trip purpose

\begin{tabular}{ll}
\hline Purpose of journey & INCIDENCE \\
\hline (L) Leisure & 58 \\
(I) Working & 19 \\
(E) Entertainment & 7 \\
(The other & 2 \\
\hline
\end{tabular}

Source: Author's edition, 2017. 


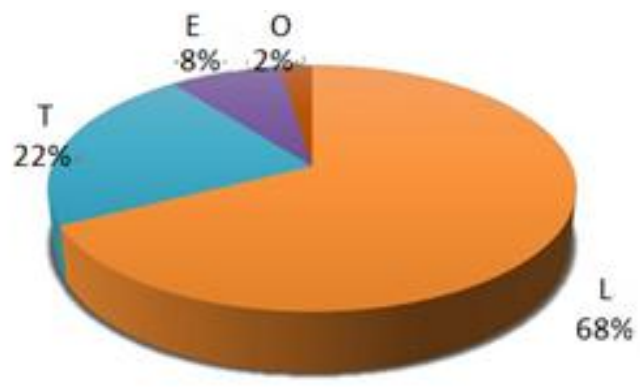

Figure 5. Trip purpose

Source: Author's edition, 2017

Table 6. $\mathrm{f}=$ Travel Frequency

\begin{tabular}{ll}
\hline FREQUENCY & INCIDENCE \\
\hline (D) Daily & 0 \\
(S) Weekly & 0 \\
(M) Monthly & 13 \\
(1A) 1 once a year & 26 \\
(2A) 2 times a year & 15 \\
(3A) 3 times a year & 8 \\
(O) Other & 18 \\
\hline
\end{tabular}

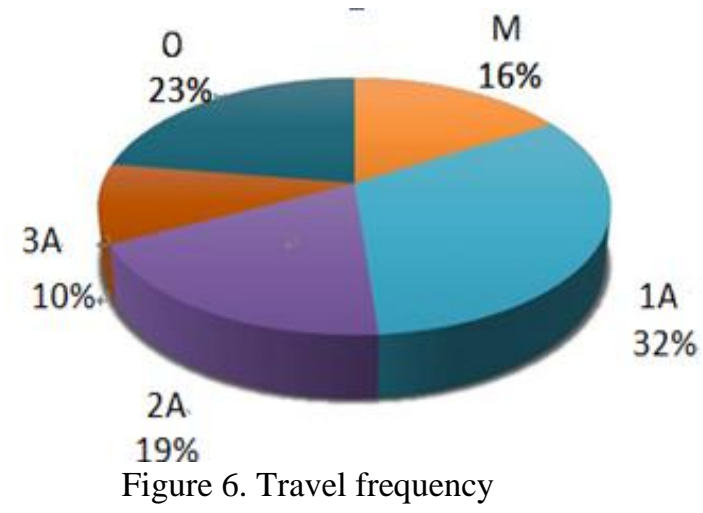

Source: Author's edition, 2017.

Regarding customer's purchase channels preferences, approximately $74 \%$ of the respondents claimed to buy their tickets by using carrier's web portals and other online sites (Figure 7)

This information is directly related with the main purpose of this research, since, as it was shown, customers are each time more purchasing by online channels, and with the urging of the smartphones and online social networks on the past decade, the process of e-commerce development became even faster.

Table 7. Purchase channels

\begin{tabular}{ll}
\hline WHERE PURCHASED A TICKET & INCIDENCE \\
\hline (AV) Travel Agency Store & 19 \\
(LC) Airline Store & 4 \\
(SC) Airline Website & 38 \\
(SV) Travel Agency WebSite & 23 \\
(The other & 1 \\
\hline
\end{tabular}

Source: Author's edition, 2017 


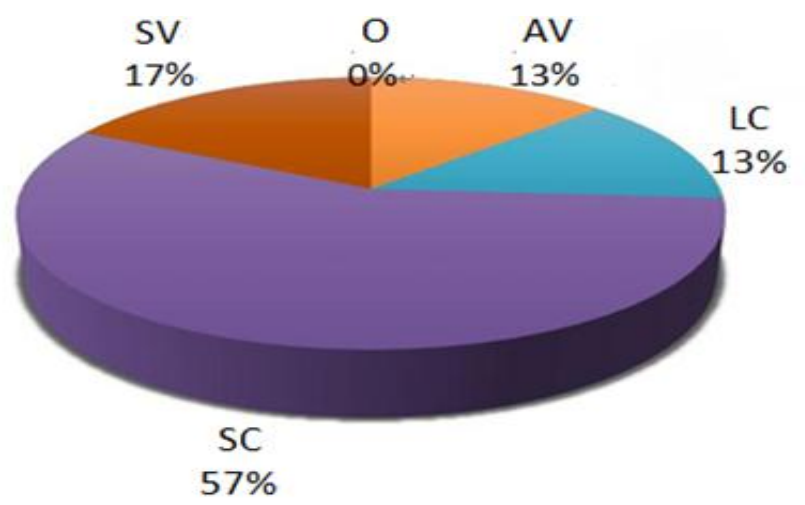

Figure 7. Purchase channels

Source: Author's edition, 2017.

On general terms, regarding the standard profile of this research, it is possible to inquiry that most of the respondents are male gender, resident of Rio Grande do Sul State, aged between 18 and 50 years and earned college education diploma. Therefore, most of the sample also claimed traveling for leisure and at least once a year.

\subsection{Airline's Choice}

On issues related to the airline's choice, respondents were asked to answer the questions as Table 8:

Table 8. Possible answers

Source: Author, 2017.

\begin{tabular}{cl}
\hline Option & \multicolumn{1}{c}{ Subtitle } \\
\hline 1 & (Cple) Strongly Agree \\
2 & (CPAR) Partially agree \\
3 & (NDNC) I do not disagree nor agree \\
4 & (DPAR) Partially disagree \\
5 & (Dple) Strongly Disagree \\
6 & (NA) Not applicable \\
\hline
\end{tabular}

The following Table 9 presents the incidence of answers to each question: 
Table 9. Effect / Responses

\begin{tabular}{|c|c|c|c|c|c|c|c|}
\hline & ISSUE / IMPACT & 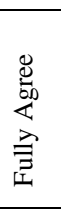 & 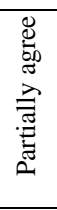 & 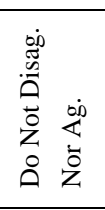 & 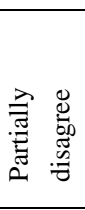 & 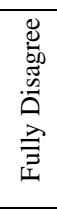 & 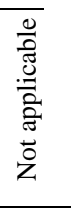 \\
\hline Q1 & The most important item for the choice is the price charged. & 51 & 25 & 2 & 1 & 0 & 1 \\
\hline Q2 & Quality of service is essential for my choice. & 34 & 31 & 10 & 4 & 1 & 0 \\
\hline Q3 & Security is a key element for my choice. & 49 & 18 & 7 & 3 & 0 & 3 \\
\hline $\begin{array}{l}\text { Q4 } \\
\text { purc }\end{array}$ & \multicolumn{6}{|c|}{ purchase fidelity. } & 8 \\
\hline Q5 & I usually choose for the most advertised airline. & 2 & 7 & 24 & 13 & 19 & 15 \\
\hline \multicolumn{2}{|c|}{$\begin{array}{l}\text { Q6 I often fly with the airline that holds a more refined image } \\
\text { than the others. }\end{array}$} & 4 & 8 & 24 & 11 & 21 & 12 \\
\hline $\begin{array}{l}\text { Q7 } \\
\text { deci }\end{array}$ & $\begin{array}{l}\text { I evaluate the airline's social networks before taking my } \\
\text { a to purchase the ticket. }\end{array}$ & 8 & 16 & 20 & 6 & 18 & 12 \\
\hline \multicolumn{2}{|c|}{$\begin{array}{l}\text { Q8 I usually choose the airline that has an updated website } \\
\text { with easy navigation. }\end{array}$} & 24 & 24 & 14 & 4 & 10 & 4 \\
\hline $\begin{array}{l}\text { Q9 } \\
\text { airlit }\end{array}$ & $\begin{array}{l}\text { I tend to follow the travel agent's guidelines regarding } \\
\text { s best choice. }\end{array}$ & 10 & 19 & 12 & 5 & 14 & 20 \\
\hline \multicolumn{2}{|c|}{ services, through chat rooms and social networks. } & 19 & 24 & 15 & 4 & 9 & 9 \\
\hline \multicolumn{2}{|c|}{$\begin{array}{l}\text { Q11 I Usually choose airlines that maintain and update their } \\
\text { social networks, feeding them with promotions. }\end{array}$} & 26 & 25 & 10 & 5 & 9 & 5 \\
\hline \multicolumn{2}{|c|}{$\begin{array}{l}\text { Q12 Usually, I tend to choose the airline that offers extra treats } \\
\text { and services during the flight. }\end{array}$} & 10 & 27 & 16 & 7 & 10 & 10 \\
\hline \multicolumn{2}{|c|}{$\begin{array}{l}\text { Q13 Airline's advertising strategies directly influence my } \\
\text { purchase. }\end{array}$} & 12 & 27 & 20 & 7 & 5 & 9 \\
\hline \multicolumn{2}{|c|}{$\begin{array}{l}\text { Q14 Usually, I check airline's reputation in costumer's opinion } \\
\text { sites like TripAdvisor. }\end{array}$} & 22 & 15 & 13 & 3 & 15 & 12 \\
\hline \multicolumn{2}{|c|}{ Q15 For me, airline's choice is not important. } & 14 & 21 & 13 & 11 & 11 & 10 \\
\hline
\end{tabular}

Source: Author's edition, 2017.

Therefore, will be presented the most relevant incidences that are related to this study. According to Table 9 and Figure 8 data, 76 of the 80 respondents, (about 95\%) fully and / or partially agreed that the most important item for the airline's of choice is the price charged (Q1). As an example that sustains this result, according to the newspaper O Estado de São Paulo (2017), since airlines have adopted the ANAC resolution 400/2016 The resolution 400/2016 Anac approves that Brazilian airlines could charge an extra fee for checked baggage, the prices of airline tickets have increased by about $35 \%$, which dropped in the number of domestic passengers into Brazilian airports.

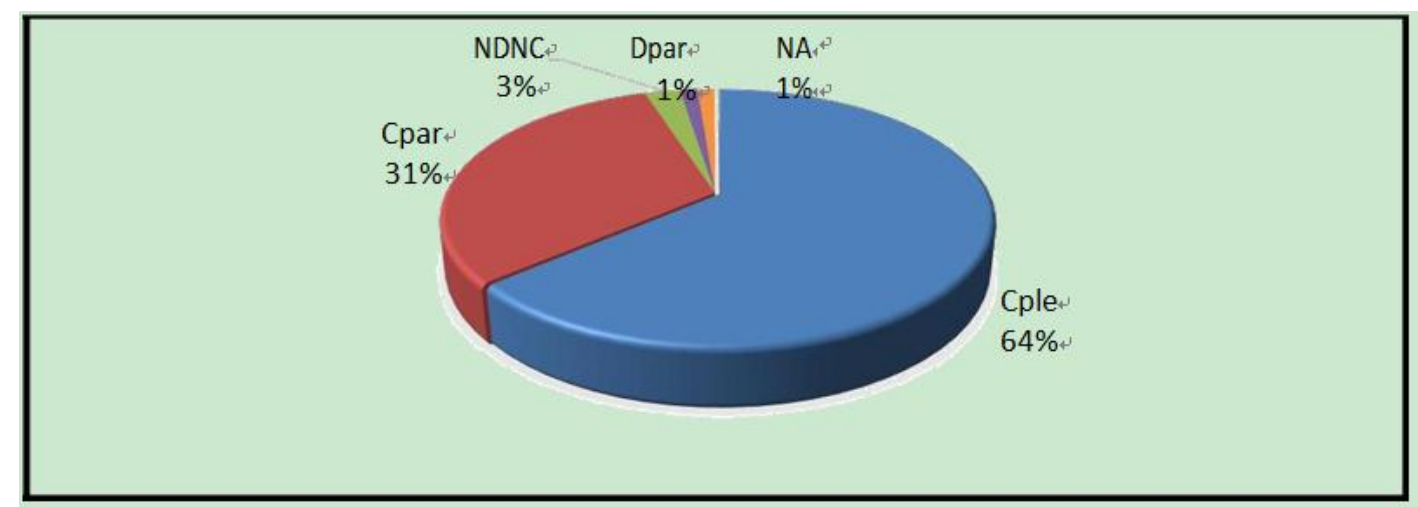

Figure 8. (Q1) The most important item for the choice is the price charged

Source: Author's edition, 2017. 
Regarding the item quality of service (Q2), $81 \%$ of respondents fully and / or partially agreed that this is the key factor for airline's choice. Therefore, for $83 \%$ of the customers, safety is a key element for the best carrier's choice. This shows, despite of the fact that Brazil is currently in one of its worst economic crisis in history, customers are still worried about other facts besides prices regarding their purpose's main reasons, as it is shown on Figure 9.

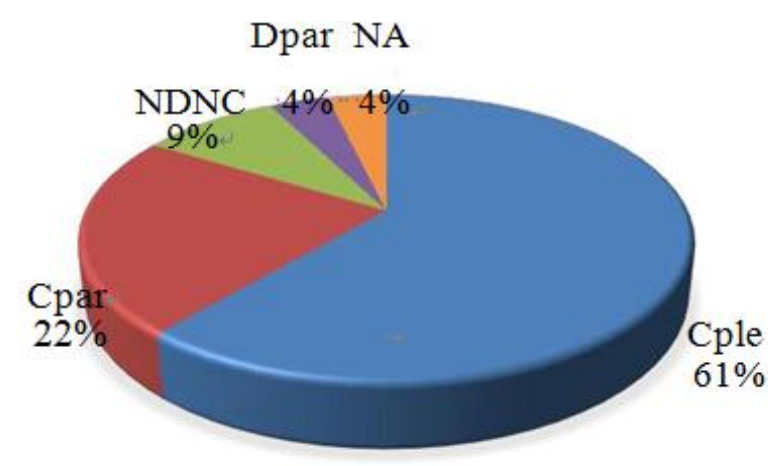

Figure 9. (Q3) Safety is a key element for my choice

Source: Author's edition, 2017.

About the airline's media visibility (Q13), about $11 \%$ of respondents strongly agreed that this is an important issue regarding carrier's choice. About this same question, $40 \%$ fully and / or partially disagreed, while $49 \%$ have claimed to be indifferent about this topic. However, when asked if Airline's advertising strategies directly influence their purchase, $49 \%$ of respondents fully and / or partially agreed, as shown on Figure 9.

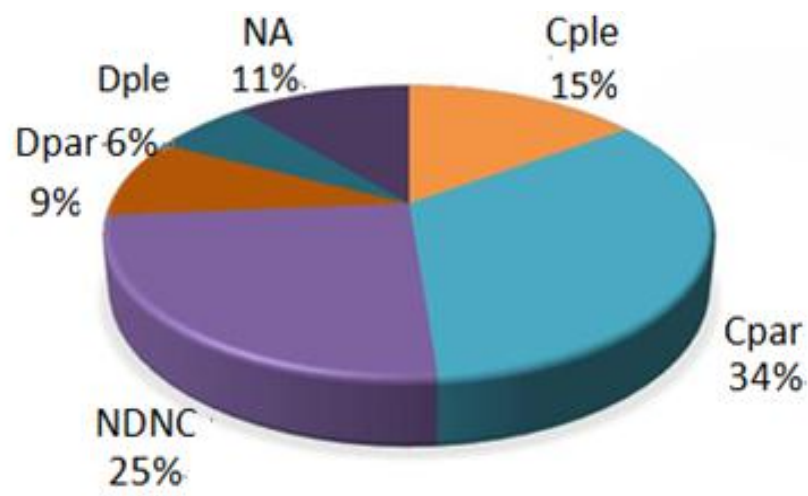

Figure 10. (Q13) Airline's advertising strategies influence on purchase

Source: Author's edition, 2017.

In order to analyze the effectiveness of the digital and relationship marketing activities carried out by leading airlines, $70 \%$ of respondents said they do not evaluate (or are indifferent) the company's social networks before buying their tickets. In relation to online sites, $60 \%$ of the sample usually choose for the airline that maintains an updated website with easy navigation. Similarly, $54 \%$ of respondents also choose companies that maintain some sort of online service, through chat rooms and / or social networks. When asked about the frequent flyer programs, more than half of respondents (54\%) agreed fully and / or partially that this is a fundamental item before choosing the airline (Figure 11). Mileage programs could be considered the greatest bond of customer's fidelity and, in a way, it could guarantee their loyalty through benefits granted, especially regarding ticket's price, which it is an essential item for the airline's choice by customers. 


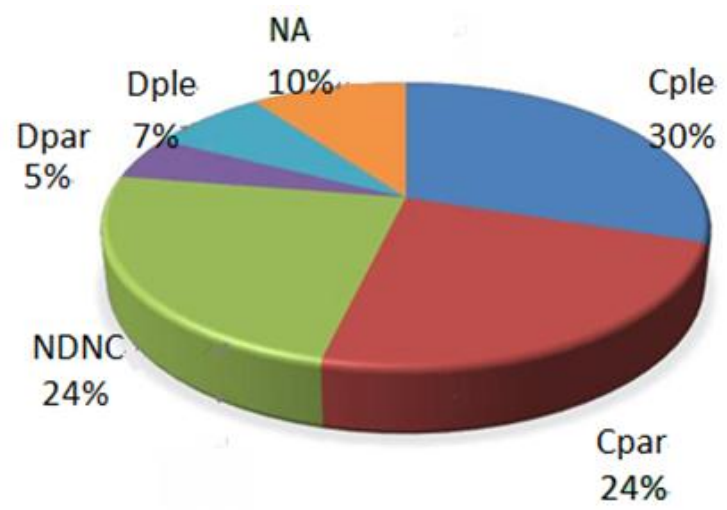

Source: author's edition.

Figure 11. (Q4) I believe that mileage programs are essential for my purchase fidelity

Probably, the most "controversial" claim of this form is Q15, which says " For me, airline's choice is not important." About $17 \%$ of the respondents fully confirmed that this is not the most important aspect on airline's ticket purchase process and $24 \%$ partially agreed to that. Another $34 \%$ of respondents were indifferent on this matter and said that the statement does not apply to your situation. Only $18 \%$ of passengers, fully and / or partially disagreed about airline type being an important variable, as shown on figure 12. According this data, it is possible to inquiry the following perspective: About $72 \%$ of the sample does not prioritize the airline at the time of purchase, even claiming mileage programs are important.

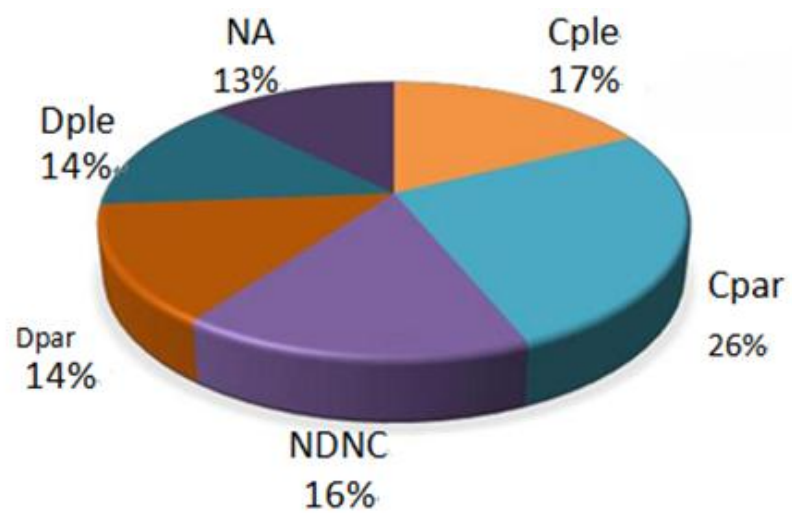

Figure 12. (Q15) For me, airline's choice is not important

Source: Author's edition, 2017.

\subsection{Ticket's Purchase}

On issues related to the airline ticket purchase process (Table 3), respondents were asked as Table 8 showed previously. The following Table 10 contains main incidences of answers to each question:

Table 10. Effect / answers incidence

\begin{tabular}{|c|c|c|c|c|c|c|}
\hline ISSUE / IMPACT & 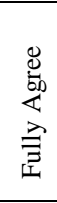 & 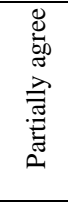 & 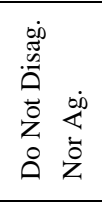 & 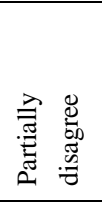 & 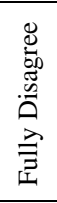 & 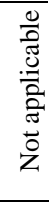 \\
\hline Q16 Price is the most important variable for me. & 51 & 24 & 1 & 2 & 1 & 1 \\
\hline Q17 Given the choice between classical buying(store) or & 53 & 8 & 3 & 8 & 5 & 3 \\
\hline
\end{tabular}
online, I choose the online purchase, even if is the same 
airline.

Q18 I give preference to classical store purchases.

Q19 On price levelling situations, I give preference to classical airline stores.

Q20 On price levelling situations, I give preference to travel agencies and / or my travel agent.

Q21 I usually tend to buy on the the place that I am better served, regardless the price.

Q22 Online purchase is always my first choice.

Q23 I tend to buy my tickets on the most comfortable way.

Q24 I take into account the opinion of friends or relatives

regarding the best way of purchasing my tickets.

Q25 I take into account online promotions and social

networking.

Q26 I feel safer when buying my airline tickets from a travel agency.

Q27 I believe it is riskier to buy airline tickets from travel agencies websites.

Q28 I prefer to buy online, since I feel totally confident of this purchase process.

Q29 I believe that the online buying process is safe.

Q30 I had prior purchase problems using online channels.

Q31 I believe on the security of buying airline tickets from travel agencies.

Q32 I prefer to buy from travel agencies, since I have a reliable agent.

Q33 I already bought tickets from travel agencies and had problems.

Q34 When having problems after an online purchase on airline's website, I had a fast and efficient service via chat rooms or social networks.

Q35 When having problems after an online purchase on travel agency website, I had a fast and efficient service via chat rooms or social networks.

Q36 For me, airline's presence on social networks is very important.

Q37 I feel fear about the after-sales a travel conglomerate.

Q38 I do not trust online shopping process.

Q39 I think it is very important to be informed about tickets promotions via email or social networks.

Q40 I understand that online prices are better than the prices charged in stores.

Q41 When buying airline tickets online, I feel safe to impute my personal data and credit information.

Q42 I usually prefer to buy online, because I believe that this is the best channel to get relevant information for my travel.

Q43 Before finishing my online purchase, I usually compare prices among all travel sites and airlines.

Q44 I think it is unnecessary to pay extra fees for the service of a professional in classical stores.

Q45 Despite knowing that there's a higher price, I prefer to buy from classical stores and make sure that I would be well assisted if there is any further problems in my trip.

\begin{tabular}{|c|c|c|c|c|c|}
\hline 15 & 9 & 10 & 9 & 18 & 19 \\
\hline 18 & 9 & 13 & 6 & 17 & 17 \\
\hline 16 & 18 & 6 & 5 & 17 & 18 \\
\hline 17 & 16 & 12 & 13 & 11 & 11 \\
\hline 50 & 14 & 3 & 6 & 6 & 1 \\
\hline 56 & 11 & 6 & 3 & 3 & 1 \\
\hline 23 & 13 & 15 & 3 & 16 & 10 \\
\hline 45 & 18 & 6 & 3 & 6 & 2 \\
\hline 15 & 18 & 17 & 6 & 14 & 10 \\
\hline 13 & 16 & 19 & 5 & 21 & 6 \\
\hline 42 & 16 & 6 & 7 & 5 & 4 \\
\hline 40 & 20 & 10 & 6 & 2 & 2 \\
\hline 11 & 9 & 6 & 6 & 17 & 31 \\
\hline 35 & 23 & 8 & 2 & 6 & 6 \\
\hline 13 & 9 & 10 & 8 & 14 & 26 \\
\hline 7 & 7 & 3 & 6 & 15 & 42 \\
\hline 13 & 12 & 6 & 4 & 3 & 42 \\
\hline 11 & 10 & 7 & 4 & 2 & 46 \\
\hline 31 & 18 & 18 & 2 & 5 & 6 \\
\hline 14 & 23 & 12 & 6 & 8 & 17 \\
\hline 8 & 8 & 10 & 7 & 30 & 17 \\
\hline 28 & 27 & 12 & 3 & 6 & 4 \\
\hline 47 & 21 & 7 & 3 & 2 & 0 \\
\hline 36 & 23 & 11 & 5 & 4 & 1 \\
\hline 37 & 15 & 10 & 4 & 6 & 8 \\
\hline 49 & 12 & 5 & 4 & 4 & 6 \\
\hline 23 & 11 & 14 & 11 & 15 & 6 \\
\hline 15 & 9 & 9 & 12 & 17 & 18 \\
\hline
\end{tabular}

Source: Author's edition, 2017. 
When asked about purchase process, 94\% (Figure 12) of the respondents fully and / or partially agreed that price is the most important variable (Q16). This concern with the price, can also be noticed in question Q43, in which about $75 \%$ of the sample said that before concluding their purchase, they usually compare prices among all travel and airlines websites. About $76 \%$ of the sample choose to purchase from websites (Figure 14), even with the option of classical purchase (store). This data shows that costumer behavior across the market are constantly walking towards e-commerce direction. Thus, advertising actions directed to this profile are extremely important, as well relationship marketing strategies.

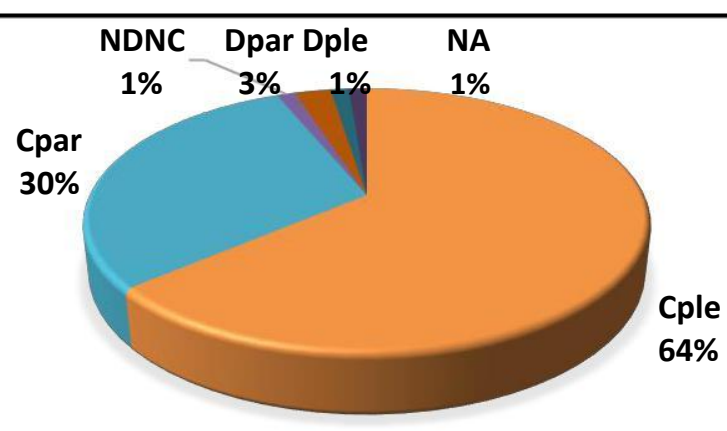

Figue 13. (Q16) Price is the most important variable for me

Source: Author's edition, 2017

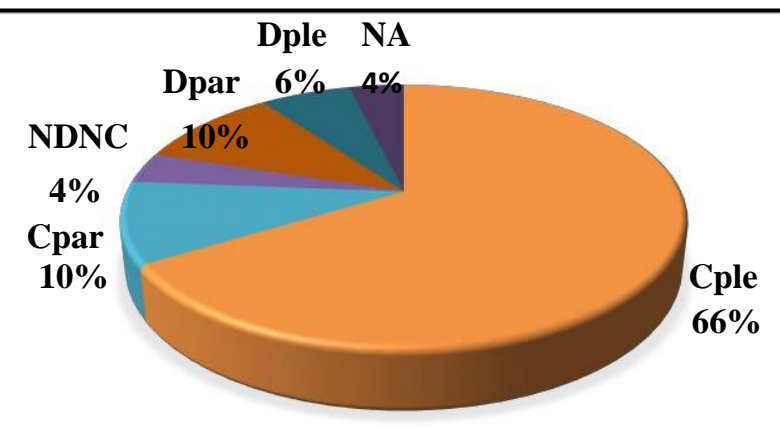

Figure 14. (Q17) Given the choice between classical buying(store) or online, I choose the online purchase, even if is the same airline

Source: Author's edition, 2017

Regarding questions Q19 and Q20, referred to price levelling between online and classic (stores) channels (airlines), 27 of 80 respondents claimed they would prefer classic purchase. The same thing occurs when the situation of equity involves a travel agency website, showing that 34 respondents would prefer classical purchase. This shows that even in the current digital age, some costumers still have a conservative profile. This data can also be related with the results of Q37, which shows that $46 \%$ of customers still don't fully trust online purchase, especially regarding after-sales services. 


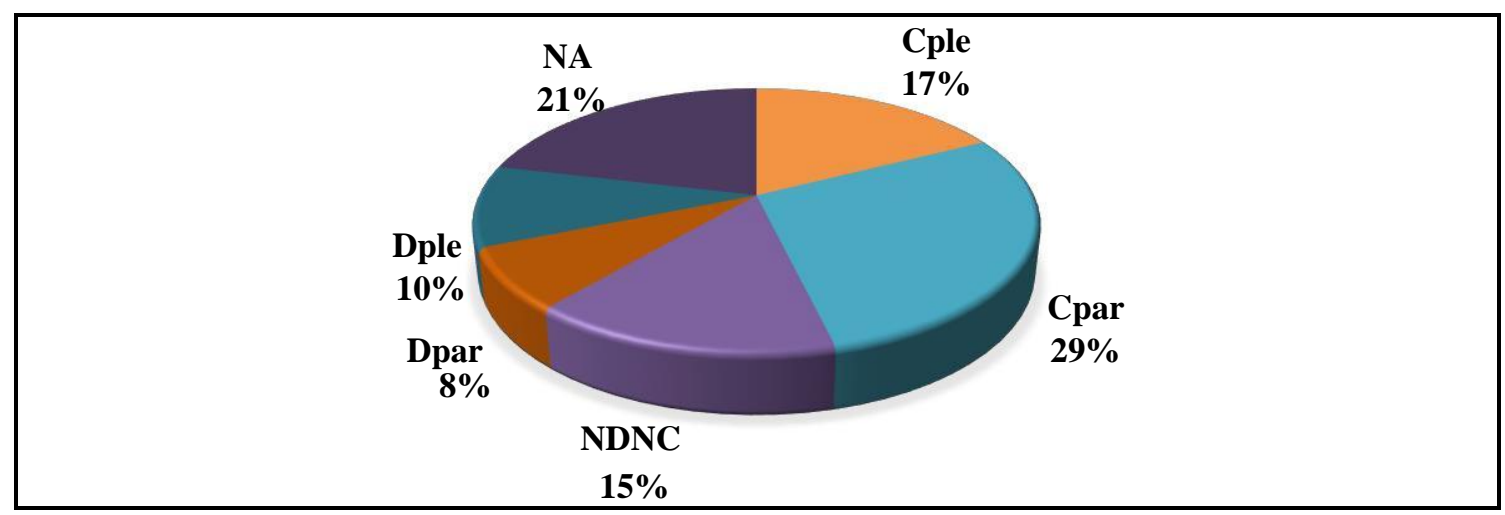

Figure 15. (Q37) I feel fear about the after-sales a travel conglomerate

Source: Author's edition, 2017

For consumers who prefer classical stores, $41 \%$ of respondents confirmed that they usually buy in places where they are best served, regardless of the price charged. Therefore, about $45 \%$ (Figure 17) of the sample confirms that takes into account friends or relatives opinions regarding the best purchase channel.

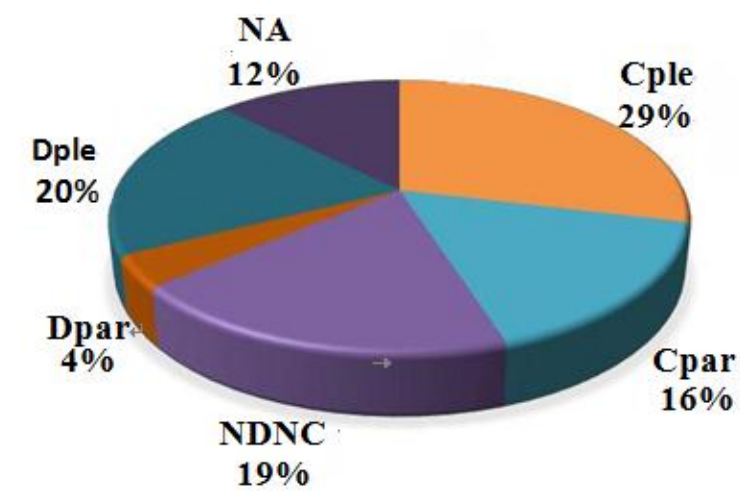

Figure 16. (Q24) I take into account the opinion of friends or relatives regarding the best way of purchasing my tickets

Source: Author's edition, 2017

About $73 \%$ of respondents believed on the security of buying airline tickets from travel agencies, and $27 \%$ also claimed prefer purchases from agencies, as have a reliable agent. Thus, $41 \%$ of respondents feel safer when buying airline tickets from a professional, against 25\% who disagree of this statement. On the issue Q45 (Figure 17) despite knowing that there's a higher price, customers prefer to buy from classical stores and make sure they would be well assisted if there is any further problems on their trips, $36 \%$ of the sample fully or partially disagreed, while $31 \%$ agreed with the statement. 


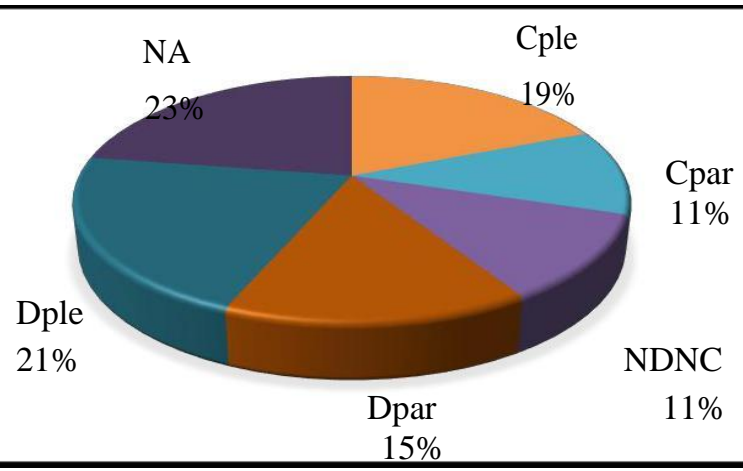

Figure 17. (Q45) Despite knowing that there's a higher price, I prefer to buy from classical stores and make sure that I would be well assisted if there is any further problems in my trip

Source: Author's edition, 2017

Approximately $80 \%$ of the sample claimed that online purchase is their first choice (Figure 18). Thus, about $75 \%$ confirmed that fully and / or partially consider that online purchase is reliable and secure. Still on this matter, $85 \%$ of respondents believed that online prices applied are better than the charged in classical stores. It is believed that airlines should always seek for ways to make the sale process quicker and as easy as possible.

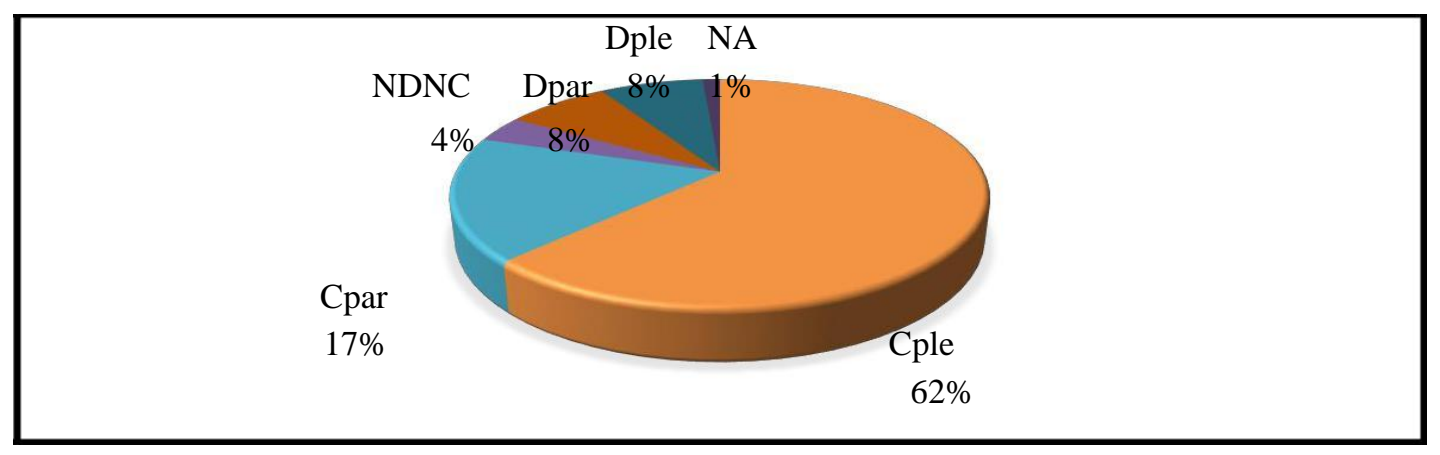

Figure 18. (Q22) Online purchase is always my first choice

Source: Author's edition, 2017

Still related to online purchase, about $74 \%$ of respondents consider to be safe imputing their personal data and credit information (Figure 19), which shows that Airlines and travel websites are investing a lot on securiteness on the past few years. On the same matter, $65 \%$ claimed that online purchase is the best channel because they could find any sort of information regarding their trips and $43 \%$ (Figure 20) considered unnecessary paying extra fees for a classic store service.

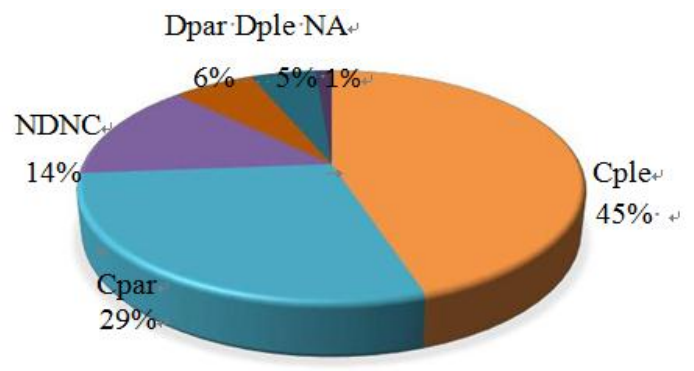

Figure 19. (Q41) When buying airline tickets online, I feel safe to impute my personal data and credit information Source: Author's edition, 2017 


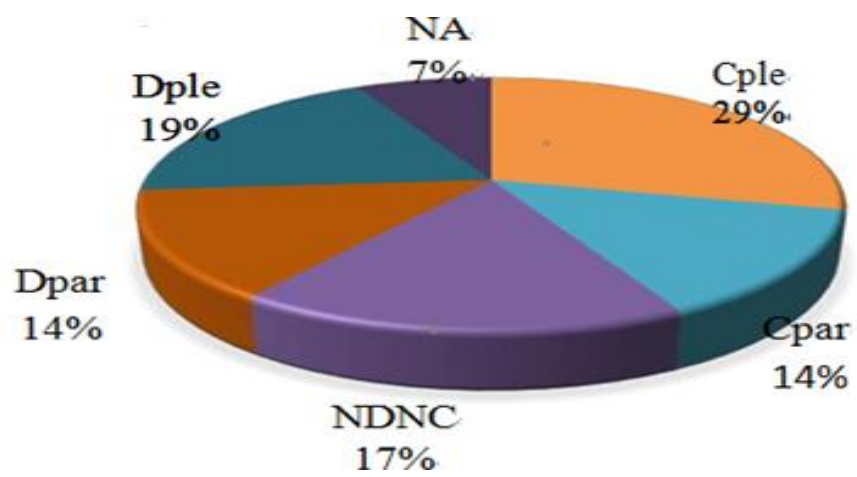

Figure 20. (Q44) I think it is unnecessary to pay extra fees for the service of a professional in classical stores

Source: Author's edition, 2017

Concerning digital and relationship marketing strategies, about $78 \%$ claimed to be important for airlines and travel agencies to use their online and social network resources as means to offer promotion rates among other benefits. Based on this data, it is valuable to consider that in general terms, communication strategies need to be constantly updated for better sales results.

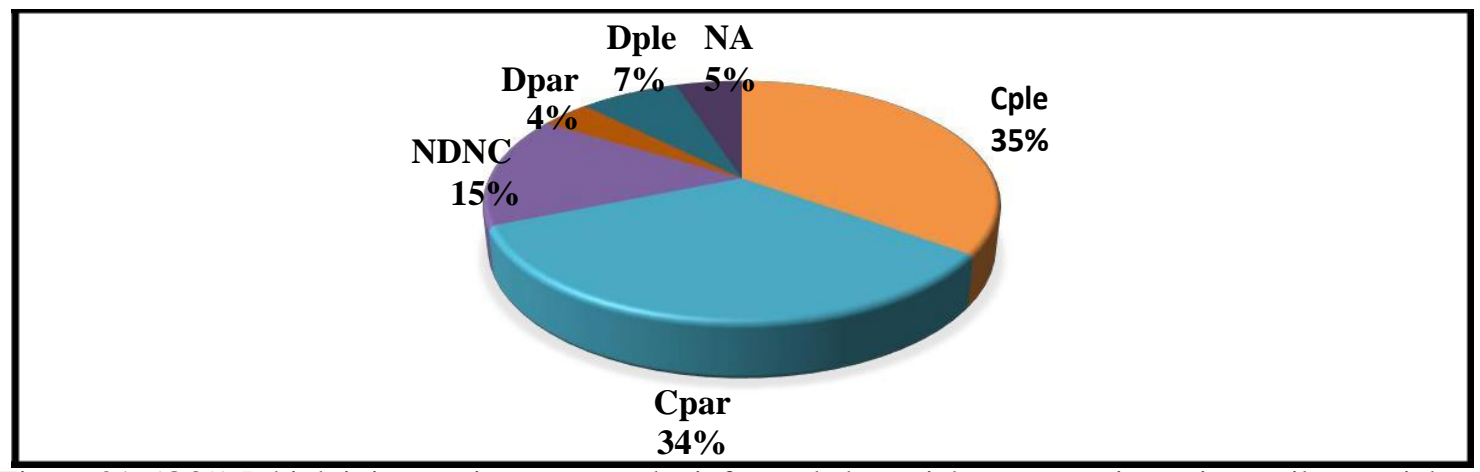

Figure 21. (Q39) I think it is very important to be informed about tickets promotions via email or social networks

Source: Author's edition, 2017

On general terms, it is possible to inquiry from this research that customers are currently preferring online purchase instead of classical store purchase since they consider that online rates are cheaper than on store rates. Another important fact is that most of customers still consider the ticket rate and extra benefits as purchase key factors and believe that airlines/ agencies online social network channels are important to improve the quality of the service on the sale process.

For those customers who still prefer classical store sales, the main reasons claimed were reliability in the physical store and in the professional agent, as well as the lack of security on the online after sale services.

\section{Final Considerations}

The present research aimed to contribute for the debate concerning the use of digital marketing and relationship marketing tolls regarding air tickets sales, as well as identify customer's purchase trends. Therefore, it can be considered that most of customers are considering firstly the price applied by airlines. In this way, online rate promotions also are important to attract and keep customers. The secureness is another key factor on the airline's choice.

Regarding online purchase, most of customers agreed that this is their first option, using airline's web sites as main channel and as source of reliable information about their trips. It was also identified that airlines and travel agencies are effectively using digital marketing and investing on online tools, where customers can easily buy their tickets and manage reservations from cellphone. Obviously, it is important to say that is required a deeper research of this subject to provide more effective and updated results. 


\section{References}

AFP World Tourism grew by 4\% in 2016. (2016). Survey-2017. Retrieved 13 March, 2017 from http://exame.abril.com.br/economia/turismo-mundial-cresceu-4-em-2016/

Brazil, Civil Aviation Secretariat-SAC. (2014). The Brazil that flies. Retrieved 20 October, 2017 from http://www.aviacao.gov.br/obrasilquevoa/index.php

Brazil, Ministry of Transport, Ports and Civil Aviation. (2017). Growing passenger traffic in nine of the ten largest airports in the country. Retrieved 6 March, 2017 from http://www.aviacao.gov.br/noticias/2017/05/cresce-movimentacao-de-passageiros-em-nove-dos-dez-maiores-ae roportos-do-pais/view

Bridi, G., \& dos Santos, M.M. (2012). Tourism's professional training and performance in travel agencies: skills. Porto Alegre EDIPUCRS.

Creswell, J.W. (2015). Research design: Qualitative, quantitative, and mixed methods (3rd ed.). Porto Alegre: Artmed.

Empresa Brasileira de Infraestrutura Aeroportuária-Infraero. (2015). Histórico. Retrieved 13 May, 2017, from http://www4.infraero.gov.br/aeroportos/aeroporto-internacional-de-porto-alegre-salgado-filho/sobre-o-aeroporto /historico/

Guimarães Júnior, A.L.C. (2012). Social media relationship management: a study of Gol airlines and Ponto Frio network, 74. (Pós-graduação em Gestão da Comunicação nas Organizações)-Centro Universitário de Brasília, Brasília.

Ibge. (2010). Censo. Retrieved 30 November, 2017, from https://censo2010.ibge.gov.br/

Longo, W. (2014). Marketing and communication in the after digital age: Rules changed (1st ed.). São Paulo: HSM do Brasil.

Ludke, M., Andres, M.E., D.A. (2012). Educational research: qualitative approaches. São Paulo: EPU.

Marin, A. (2007). Information Technology in travel agencies: in search of productivity and added value. First reprint. São Paulo: Aleph.

Morrison, Alastair M. (2012). Marketing of hospitality and tourism (4th ed.). São Paulo: Cengage Learning.

Otaviani Longhini, F., Poggi, E., \& Borges, M. (2005). The influence of internet on tourism market share: A case study of travel agencies from Piracicaba (SP) and neighborhood. Caderno Virtual de Turismo, 5(3).

Palhares, G.L. (2001). Tourist Transport. Sao Paulo: Aleph.

Petrocchi, M. (2005). Hospitality: Planning and Management. São Paulo: Futura.

World Tourism Organization-UNWTO. Por qué el tourism? (2016). Retrieved 12 May, 2017, from http://www2.unwto.org/es/content/por-que-el-turismo

YIN, R.K. (2010). Case Study: Design and Methods (4th ed.). Porto Alegre. Bookman. 